\title{
Exploring the Autonomy of South African School Science Students when Doing Investigative Inquiries for a Science Fair
}

\author{
Umesh Dewnarain Ramnarain ${ }^{1 *}$ \\ ${ }^{1}$ University of Johannesburg, SOUTH AFRICA \\ Received 27 May $2020 \cdot$ Accepted 18 August 2020
}

\begin{abstract}
This mixed methods research explored the autonomous experiences of South African school students when participating in a science fair. A prominent global goal for school science education is for students to partake in scientific inquiry in order to acquire understanding of science concepts, the processes and skills of science, and the nature of science. This places a demand on teachers as it requires a change in pedagogy from a teacher-centred to a student-centred approach. Student autonomy, has been described as both a rationale for and a characteristic of students doing scientific inquiry. In this research, a quantitative survey questionnaire was administered to 50 students participating in a science fair. The questionnaire sought to establish the autonomy level of students when doing their investigative inquiry projects and the degree of support they received. Thereafter, 5 students were interviewed to elaborate upon their responses and to describe in detail their experiences of doing the projects. The findings of this study revealed that the students enjoyed optimal autonomy and perceived their experience as being empowering and stimulating. It is also suggested that science fairs can provide an opportunity for students to enjoy autonomy in choosing their own topic for inquiry, in designing the inquiry, in doing the inquiry, and arriving at their own conclusions. This autonomy can enable students to experience authentic inquiry, show their creativity and demonstrate critical thinking skills.
\end{abstract}

Keywords: scientific inquiry, science fair, authentic inquiry

\section{INTRODUCTION}

Science fairs for school students have a long tradition in many parts of the world (Bencze \& Bowen, 2009; McComas, 2011). Science fair projects can enable students to enjoy autonomy in doing inquiry projects, and other benefits associated with student-initiated inquiry. In doing a science fair project, students have an opportunity to conduct an investigation of a phenomenon that is of interest to them (Gomez, 2007). A qualitative study by Schmidt and Kelter (2017), showed that science fair participation increased student understanding of science content knowledge, and positively influenced the attitudes of the majority of students in the study toward STEM courses and careers. Such involvement also engages students in high-sense practices of science that are enumerated in the Framework for K-12 Science Education (National Research Council, 2012) and the Next Generation Science Standards, 2013).
These practices that are often associated with authentic inquiry include "analyzing and interpreting data; constructing explanations; engaging in argument from evidence; and obtaining evaluating and communicating information" (NRC, 2012, p. 43). Such practices are least emphasized by teachers in school science (Koomen et al., 2018). However, there is a gap in research about the influence of science fair participation on science inquiry learning experiences. This research investigated the experiences of South African science students when doing investigative inquiries for a science fair.

In South Africa, such fairs (known as science expos) have been the preserve of students from privileged socio-economic background who attend private schools or schools located in affluent suburbs. However, since the dismantling of the racially segregated Apartheid state, policy has been put into place to redress the historical imbalances of the education system that previously advantaged white students. In the Apartheid

(c) $\mathbf{2 0 2 0}$ by the authors; licensee Modestum. This article is an open access article distributed under the terms and conditions of the Creative Commons Attribution License (http://creativecommons.org/licenses/by/4.0/).

$\checkmark$ uramnarain@uj.ac.za (*Correspondence) 


\section{Contribution to the literature}

- The research informs on student experiences of participating in a school science fair.

- The research reports that science fairs provide an opportunity for students to acquire autonomy in scientific investigations.

school system, students based on race attended separate schools and also experienced different curricula. Black students experience a science curriculum that was disempowering and suppressive (Naidoo \& Lewin, 1998). The curriculum gave limited attention to scientific literacy, with a strong focus on teacher-directedness and the transmission of scientific knowledge (Le Grange, 2008). A fundamental principle underpinning the new curriculum in post-Apartheid South Africa is studentcenteredness and student autonomy. In school science, this imperative is revealed in the attention that is given to inquiry-based science education that forms the cornerstone of the national school science curriculum.

Scientific inquiry is regarded as an important curriculum goal in school science education in South Africa, and also globally, with school curriculum documents strongly advocating that opportunities be provided for children "in asking scientifically valid questions, setting up investigations, collecting and analyzing data, and coming to some conclusion based on the data collected" (Crawford, 2014, p. 515). The South African school science curriculum known as the Curriculum and Assessment Policy Statement (CAPS) document underlines the goal for inquiry-based learning through Specific Aim One that states 'the purpose of Physical Sciences is to make students aware of their environment and to equip students with investigating skills relating to physical and chemical phenomena' (Department of Basic Education, 2011, p. 8). The CAPS for Natural and Life Sciences expresses a similar goal.

Inquiry-based learning allows students to develop "key scientific ideas through learning how to investigate and build their knowledge and understanding of the world" by using "skills employed by scientists such as raising questions, collecting data, reasoning and reviewing evidence in the light of what is already known, drawing conclusions and discussing results" (Inter-Academy Panel, 2012). Student autonomy has been described as both a rationale for and a characteristic of students doing scientific inquiry (Ramnarain, 2014). The curricular underpinnings of an inquiry-based approach become most evident when this approach is contrasted with a traditional approach to science teaching. In the traditional science curriculum, the student plays a passive role in learning, and the teacher exerts much control over the learning environment. Here the transmission of scientific knowledge to students is the overarching imperative. Some of the reported benefits of students doing autonomous inquiry include that it stimulates an interest in science (Mupira \&
Ramnarain, 2018; Potvin \& Hasni, 2014), leads to conceptual (White \& Frederiksen, 1998), improves an understanding of the nature of science (Gaigher, Lederman, \& Lederman, 2014; Kremer, Specht, Urhahne, \& Mayer, 2014), develops higher-order thinking (Conklin \& Manfro, 2012; Tindangen, 2018), and facilitates collaboration between students (Hofstein \& Lunetta, 2003).

\section{STUDENT AUTONOMY IN SCIENTIFIC INQUIRY}

The strong support for a student-centred school curriculum is well documented over the past 50 years. Jean Jacques Rousseau (as cited in Lawrence, 1970) believed in a student-centred curriculum, which ultimately results in deepened student understanding. John Dewey posited a pedagogical approach where students should be more active in their learning. He supported problem or thematic based learning where the content was selected by adults alone (Travers \& Rebore, 1987). Later, Bruner (1966) supported Dewey's ideas and further said that subject matter could be changed to fit the child's individual needs by making the activities open-ended. Bruner believed that students should be scientists in their own inquiry. The value of students having autonomy in science learning was recognised by Sund and Trowbridge (1973) who stated that "the greater student involvement, the greater the learning" (p. 65). They believed that the mere assimilation of knowledge is a very limited view of learning. In their view learning involves those total aspects that contribute to the individual becoming a fully functional person.

The theoretical underpinnings of constructivism advocate strongly for students to have autonomy when doing scientific inquiry. According to this perspective, learners should be entrusted with setting their own goals for inquiry, and be responsible for taking decisions when doing inquiry (Driver \& Bell, 1985). Experiential learning is a key tenet of constructivism, and knowledge construction happens due to first-hand experiences when phenomena from the environment are investigated (Grabinger \& Dunlap, 1995). Fosnot (1996) opines in this setting "the traditional hierarchy of the teacher as the autocratic knower and student as the unknowing, controlled subject studying to learn what the teacher knows begins to dissipate as teachers assume more of a facilitator's role and students take on more ownership of the ideas" (p. iv). Therefore, due to its constructivist underpinnings, scientific inquiry 
necessitates that students are provided with optimal autonomy when engaged in such learning experiences.

A constructivist perspective of learning recognises that students bring to science learning a range of alternative conceptions of phenomena that they form to make meaning of the physical world (Driver, 1983). Constructivist teachers are aware that these conceptions formed by students are often non-scientific and based on naïve understandings of the world. Students tend to be inconsistent in their applications of these understanding to different contexts (Hamza \& Wickman, 2007), and as a result they incorrectly apply them to situations where they do not work (diSessa, Gillespie, \& Esterly, 2004). In traditional teacher-centred pedagogy, such misconceptions are often undetected by teachers, and even when identified they are resilient to change (Wandersee, Mintzes, \& Novak, 1994). Uncovering these misconceptions or naïve conceptions forms the backbone of a constructivist lesson. In order for students to relinquish their misconceptions about a particular topic, Bächtold (2013) maintains that the following two steps need to happen. First, students' prior conceptions on a topic needs to be elicited. Second, the teacher needs to create a cognitive conflict in students' minds that confronts their prior conceptions, and allows them the opportunity to form new beliefs. In other words, cognitive conflict needs to be induced in order for conceptual change to take place. When students become dissatisfied with their existing explanations, and are unable to explain phenomena, this creates an opportunity for them to embrace alternative conceptions that seem plausible and appear to be more useful (Hewson \& Lemberger, 2000).

However, despite strong empirical and theoretical support for students to have autonomy in doing scientific inquiry, this remain an elusive curriculum goal in South African with science learning being predominantly controlled by the teacher (Ramnarain \& Moosa, 2017) and classrooms worldwide (Crawford, 2014). Reasons that are advanced for this include large classes (Onwu \& Stoffels, 2005), a lack of resources (Rogan \& Aldous, 2005), a lack of time (Anderson, 2007) inadequate teacher development (Capps, Crawford, \& Constas, 2012), pressure of high stakes examinations (Falk \& Drayton, 2004).

This study investigates the experiences of students at a national schools science fair hosted by a South African university. Students are allowed to enter either their projects either individually or in a group of 2 or 3 . The science fair is considered an extra-curricular activity, and not mandated by the official school science curriculum. Although student participation is voluntary, it is a great accolade for schools when their students participate and do well, and so teachers strongly motivate their students to participate. The teachers are expected to act as mentors to participating students. The projects are judged according to criteria such as novelty of the idea, the application of scientific method, clarity and coherence in the presentation of data and material, thoroughness and rigour of research, in-depth knowledge, visual appeal of the poster, and the ability to communicate ideas verbally. The projects which are entered often relate to topics covered in the school curriculum. Students can choose to investigate a scientific phenomenon related to any one of 13 categories in science. These include amongst others agricultural sciences, chemistry and biochemistry, computer sciences \& information technology, earth sciences, plant sciences, and physics, astronomy and space sciences. The students can access an online guide on the science fair that is uploaded by the organisers. The guide provides the students with information on how a research plan may be developed, and also guidelines on how their project report can be displayed on a presentation board.

This research investigated the following question:

What are the experiences of students doing scientific inquiry investigations at a science fair with regards to autonomy?

\section{RESEARCH DESIGN AND METHODOLOGY}

This research adopted a mixed methods design with a "explanatory sequential mixed methods" approach (Creswell, 2014). In this two-phased design, quantitative data is collected and analyzed in the first phase. The results from the first phase are then used in planning the second phase that is qualitative in nature. This enables the researcher to "collect both quantitative and qualitative data, merge the data, and use the results to best understand a research problem" (Creswell, 2002, p. 564). Johnson and Onwuegbuzie (2004) describe mixed methods research as the third research paradigm after the quantitative and qualitative paradigms. They state that "the goal of mixed methods research is not to replace either of these approaches but rather to draw from the strengths and weaknesses of both in single research studies and across studies" (p. 14). A mixed methods design therefore combines a deductive inquiry that serves to confirm what one expects, and an inductive inquiry that aims at explaining patterns.

In the quantitative phase of the study, a 5-point Likert scale questionnaire comprising of 20 items was administered to 50 students who participated in the science fair. Here students were asked to respond to statements which related to the degree of autonomy they received in doing the science fair scientific investigations. The options for each statement were ranged from 1 (never) to 5 (always). The questionnaire items were clustered according to the following four phases of doing a scientific inquiry (constructs): identifying the questions; planning how to investigate the question; carrying out the investigation and collecting data; and drawing conclusions. The internal 
Table 1. Constructs, internal reliability and sample items

\begin{tabular}{lcc}
\hline Constructs & Cronbach's alpha & Sample item \\
\hline Identifying the questions & 0.88 & We decide on what variables to investigate \\
Planning how to investigate the question & 0.71 & We decide what data to collect \\
Carrying out the inquiry & 0.75 & We make measurements and observations to collect the data \\
Drawing conclusions & 0.80 & We analyze the data to arrive at a conclusion \\
\hline
\end{tabular}

Table 2. Statistical results of questionnaire survey

\begin{tabular}{lcc}
\hline Constructs & Mean & Standard deviation \\
\hline Identifying the questions & 4.1 & 0.3 \\
Planning how to investigate the question & 4.3 & 0.5 \\
Carrying out the inquiry & 4.5 & 0.6 \\
Drawing conclusions & 4.8 & 0.4 \\
\hline
\end{tabular}

reliabilities of the constructs were investigated by computing Cronbach's alpha for each scale using the SPSS software. The Cronbach alpha of the scales ranged from 0.71 to 0.88 , and this reflected strong internal reliability of each scale (Cohen \& Swerdlik, 2010). Table 1 describes each of the constructs in the questionnaire, and displays the Cronbach's alpha for each scale.

Mean score calculations were performed for responses to items related to each construct in order to identify general trends in autonomy across the phases of scientific inquiry. Standard deviations for each construct were calculated in order to report on the degree of consistency in responses for each construct.

In the second phase of the study, interviews were conducted with a sub-sample of students who responded to the questionnaire survey. Interviews were conducted with 5 students who had indicated a higher degree of autonomy in doing the science fair project. The interviews provided an opportunity for the researcher to probe students on their questionnaire responses, and also to ask them to elaborate on their autonomous experiences during each phases of the scientific inquiry. It is for this reason that students who had indicated a high degree of autonomy in doing the project from the survey were purposefully selected for this phase. The interviews were audio--recorded for later transcription and analysis. The interview data were coded inductively by reading through the raw data transcripts, such that codes emerged bottom-up from the data (Saldana, 2009). Once all data were coded, the generated codes were analyzed for similarity in their meaning. Codes with a shared meaning were then grouped together into subthemes, with these sub-themes later clustered into themes (Saldana, 2009). A codebook was be developed and then shared with another researcher who applied the codebook in independently coding the interview data. Cohen's Kappa was then be calculated to assess the inter-rater reliability in coding between the researcher and the second coder (Miles \& Huberman, 1994). The Kappa was computed as 0.88, and this suggests substantial agreement (Landis \& Koch, 1977).

\section{RESULTS}

The results are presented in the following two sections. Firstly, the results on the extent to which students acquire autonomy when doing science fairs projects is presented. Trends are elaborated upon from interview data. Secondly, two cases on student experiences in doing investigative inquiries is presented.

\section{Student Autonomy in Doing Science Fair Investigative Inquiry Projects}

The findings with regards to student autonomy are presented according to the following themes.

The statistical results from the questionnaire survey are shown in Table 2.

The mean scores for the constructs need to be interpreted in terms of the 5-point scale that was used for the item responses $(1=$ never; $2=$ seldom; $3=$ sometimes; $4=$ often; $5=$ always).

The findings with regards to student autonomy are presented according to the following themes.

\section{Theme 1: High autonomy in choosing the question}

A mean score of 4.1 for 'Identifying the question' suggests that students are 'often' involved in coming up with a question for the science fair scientific inquiry. A low standard deviation of 0.3 suggests a consistency in their choices for this construct. In the interviews, the students were to elaborate upon this autonomy in identifying questions. They commented that in formulating their own questions, they felt empowered and in control of the inquiry. They also remarked that it was an opportunity to pursue their own interests. Below are some excerpts to illustrate this:

I could choose what I wanted to do. It gave me a choice of choosing something close to my hobby. This is different from pracs (practical work) at school time where we are given and told to do it.

Very nice to investigate what is relevant to what I like and enjoy. I enjoyed the fair for that reason so I could show everyone that is my passion. 
It is also evident from the above excerpts that these students had a high self-concept, with confidence in their own ability.

\section{Theme 2: Much responsibility in planning the investigative inquiry}

In 'Planning how to investigate the question' a means score of 4.3 reveals that students enjoyed much autonomy in this phase of the inquiry. A standard deviation of 0.5 reflects much coherence in the manner in which the students response to items on this construct. Again, students were seldom entrusted with this responsibility in school practical activities, with procedures generally given to them to follow as a 'recipe'. Here are some comments in this regards.

At school the teachers provide a plan, something like steps for us to follow. We just do it and the experiment most times will work out well.

We get is all in a worksheet from my teacher. We know exactly what to do, but for the fair I decided how I wanted to do it.

\section{Theme 3: Highly involved in carrying out the inquiry}

For 'carrying out the inquiry' a score of 4.5 indicate that students almost 'always' conducted the inquiry. A standard deviation of 0.6 affirms the consistency with which students responded to items on this construct. Although students did have some exposure to carrying our experiments at schools, they commented that for the science fair, there was minimal guidance. This guidance in most cases was from their parent or a family member who would supervise them especially when there was a procedure when safety was a concern. This is revealed in the excerpts below:

I often worked alone when doing the experiment, but my dad used to keep a close eye so that nothing could go wrong.

At school we have the teacher hovering over us but for the fair, I was free to investigate. My big brother who is at varsity sometime would watch out that nothing exploded or could get damaged.

\section{Theme 4: High level of autonomy in drawing the conclusion}

A mean score of 4.8 shows that student had a high level of autonomy in 'Drawing conclusions', and the low standard deviation of 0.4 indicated consistency in responses. The students shared their excitement upon reaching their own conclusions below.

This was the fun part after plotting the data and to see a curve. We also did calculations to get to a conclusion.
I was able to come to a conclusion on my own. I was nice to see that I found out what I had expected. It confirmed my prediction. It was not like I was told this is what you should arrive at but I got to it on my own.

It is clearly evidence that across all four phases, students enjoyed much autonomy in doing the scientific inquiry for the science fair.

\section{Cases of Students Doing Science Fair Projects}

Based on the data collected from the interview, two cases of students doing science fair projects are narrated. The two projects under consideration are titled 'Indicators of maize silage quality' and 'Flammability of difference fabrics'. A discussion of the students' experiences in doing these projects is now presented.

\section{Science fair project on "Indicators of maize silage quality"}

This project was a joint effort by two grade 10 male students, Joseph and Patrick (pseudonyms), and investigated the factors which influence the quality of maize silage. The teacher gave the student the entry forms and other relevant information which came from the organizers. Their science teacher encouraged them to participate in the expo, however, they were not compelled to do so. The science fair project was therefore not used for assessment in school science.

They both live on a farm and their fathers are farmers. The idea for the project was stimulated by their home context, and also that they had an interested in farming processes. Silage is food for the cows in winter and so the quality of the silage is important. Due to their interest in cattle farming, they felt the need to investigate the quality of silage. Their display was made up of a poster which had the research question, a description of the plan, the results collected, and the conclusion made. There were also samples of silage collected during the investigation. The research question was, "What factors affect the quality of maize silage." In the plan the students described four samples of the silage which were taken from different locations in the pit and the tests which were conducted on the silage. The tests included a smell test and a chemical test where the $\mathrm{pH}$ was taken. The students indicated that they chose the project as they felt it was very relevant to their present circumstances. Joseph explained this as follows:

Both of our dads are farmers. We just thought that we may as well do a project on silage. We knew that there were lots of different pits to put silage into. We wanted to know how to make the best silage. Patrick's brother who is at agricultural college also thought that we should do something in silage. Also, at home we have lots of information on it. (Joseph, interview) 
The information that was needed to conduct the test on the silage was obtained primarily from the internet. Patrick's brother who is a student at an agricultural college, was always on hand to render assistance whenever it was necessary. They collected and analyzed the samples on their own. In the following excerpt from the interview, the students explain how the testing of the silage requires specialized scientific knowledge:

Patrick: Well, we wanted to do as many tests as we could. The first one we decided to do was smell because you can smell if something is off or sweet. Sample one had a sweet hay-like smell. That was because it had been hot. Sample two had a pleasant lactic acid smell because it is moist but not too moist. Sample three which is on the side had a strong offensive, rancid smell. Sample four because it was so slushy and beginning to rot, had a rotten smell. $\mathrm{pH}$ is important because it shows you what bacteria you have got in your pit. You get your bacteria that convert sugar to starches and you get your bacteria that ferment it. You want that bacteria to die off at a certain stage. When the oxygen is finished they must die off. The $\mathrm{pH}$ level shows you that they have died off and they have fermented at the right stage.

Interviewer: How did you learn about all these tests?

Joseph: We did lot of research using the internet. We got into sites on agricultural science. Patrick's brother is studying at Cedara (agricultural college). He was always available to help. He gave us good advice on the type of tests that could be used on the silage. He allowed us to use his books on agriculture.

The above excerpts also reveals that both students were intimately involved in the research. Based on the analysis of data that they collected, they were able to formulate a conclusion on the quality of the silage. The student when asked about the involvement of the teacher in their project work, answered that he guided them when they approached him for help. The teacher helped them become more focussed on the problem they were investigating. The teacher also gave them advice about the tests they were planning to do on the silage. The following response from Joseph illustrates this:

He just guided us. We went to him from time to time. We wanted to cover all the aspects maize...like planting, crop spraying, preparation of the land...so we had a general idea and the teacher took us down a definite path. Also, we were a bit confused on what test we should perform on the silage. The teacher helped us a little bit on what test we could do. (Joseph, interview)

This project showed how the first-hand experience and knowledge of a topic led to an investigation question. Both students worked on a farm and so the topic of silage was something that interested them. They could also draw knowledge from their fathers who were both farmers and a brother who was studying agricultural science. The teacher support was also evident as the teacher guided them when they needed help.

\section{Science fair project on 'Flammability of difference fabrics'}

This project was carried out by two grade 10 female students, Nonhlanhla and Prudence (pseudonyms). The aim of the projects was to investigate the flammability of different fabrics, such as cotton, nylon, polyester and silk. The investigation question which led to this inquiry was "Which fabric will take the shortest period of time to burn?". The students indicated that the idea for the inquiry was entirely their own and was stimulated by a talk that was delivered at their school by the local fire department on safety measures to prevent a fire. Based on this talk where the presenter had warned about the flammability of materials, they felt a desire to investigate how different materials burn. They indicated that they discussed the idea with their teacher, and he suggested that they design an experiment on how to do this.

The students also assumed complete autonomy in designing the experiment. They had just learnt in class about independent, dependent and control variable, and that they was able to apply that knowledge in formulating a hypothesis for the experiment, and planning an experiment where the relationship between variables could be investigated. They were able to arrive at a set of procedures on how to conduct the inquiry. They appeared to take much pride in being able to come up their own plan. This is evident from the following interview excerpt:

I never thought we could do this on our own. We did readings on some other experiment and how these were done. The plan was all our own, and we did ourselves. Miss Lewis (their teacher) check it for us and made a few comments, but it was our own work in the end. (Nonhlanha, interview)

The students performed the experiments and collected the data on their own. They were supervised by Nonhlanhla's father. They elaborated upon this phase of the inquiry as follows.

This was the fun part of it. We used the methylated spirits to burn the materials one at a time, and then recorded the time for each to burn completely. It burnt slowly, so no real danger, but 
my dad kept an eye on us. (Nonhlanhla, interview)

Yes, I agree it was really cool. This was really exciting compared to some of the stuffy we do at school. It felt like a real scientist for a change. (Prudence, interview)

The students also reflect on their data analysis, and how they arrived at a conclusion. They recorded the data in a table of results, and constructed a bar graph to represent their results. They was quite intrigued by their findings, and this stimulated in them a need to want to explain their findings. They reflected on this experience as follows.

We took down the readings, and put it down on a table. We could see very clearly that the type of fabric was playing a role. The cotton really burnt fast. It was quite different to the other ones. We wanted to know why it was so. I check on some other similar studies, and I found out it was to do with the circulation of oxygen. When the oxygen can moved more easily through the fibres, it burns faster. (Prudence, interview)

The students were asked about future research they may want to do that related to this inquiry. They responded that they would want to also look at how the dyes used in the fabric could be a variable in affecting the flammability in fabrics. They stated this as follows.

\section{I think we could take this further. We could look} at other things in fabric such as the dye that is used. Some are natural dyes and others are manufactured. Which is safer for the fabric? (Nonhlanhla, interview)

This science fair project like the previous project showed the student having much autonomy over all stages of the investigation. The initial idea for the project and the investigation question was the students'. The support which they received was minimal. The worked independently, and only called upon an adult to supervise them when they were doing the experiment that involved burning the fabric. As with the previous science facir project, the teacher involvement was minimal.

\section{DISCUSSION AND CONCLUSION}

The findings of this study that investigated the autonomy that students experienced when participating in a national science fair, revealed that the investigative inquiry projects were student-initiated, with them enjoying autonomy across all four phases of the inquiry process. A study by Paul, Lederman, and Groß (2016) shows that students' willingness to participate in science competitions depends on their self-concept, experience of competency, and previous participation. From the interviews it was evident that these factors were also evident in the decision of students to enter the science fair.

The two cases reflected that students have complete autonomy over the inquiry stages when doing the projects. The initial idea for the project came from the students and appeared to be stimulated by a certain interest that they had in a particular field of science. The support was derived mainly from family members. This out-of-school support students received from their parents was also highlighted in a study conducted by Syer and Shore (2001) which showed the key role played by parents in helping students formulate the idea for the project, purchasing of equipment, providing transport when necessary, and in connecting the students with experts in the field. In doing the projects that were described, students received only limited support from their teachers. Once students decided what they wanted to do, they sought the opinion of the teacher on it. The teacher made suggestions when necessary. After the projects had been done, the teachers commented on them, and where necessary, changes were made. Two points stand out which make science fair projects different from classroom investigations. Firstly, where teacher support was provided, it was limited to making suggestions, and only when students solicited such support. The students were in complete control of the investigations, and appeared to thrive in this autonomy that was afforded to them. It was a refreshing experience compared to doing practical at schools that were mainly scripted, and where students were stifled in their creativity. Secondly, the inquiry projects were authentic in that they has "much in common with the practices of the scientific community" (Wang \& Hodson, 2009, p. 110). According to Hume (2009) if students are to engage in authentic scientific inquiry and develop a tacit or intuitive knowledge "they too need to participate in and experience independent, genuine investigations where the solution to the problem is not obvious" (p.35). The investigative inquiries pursued by students for the science fair in large measure gave the sense of being authentic in nature. Science fairs therefore have the potential to provide students with the opportunity to do authentic inquiry. This is an opportunity that is seldom afforded to them in school science.

There is a dearth of knowledge on the learning outcomes, which result from the participation in science fairs, as well as the factors that inform these outcomes (Paul, Lederman, \& Groß, 2016). Further research is needed to determine the effect of science fair participation that on their self-efficacy to do inquiry. Schmidt and Keller (2017) also suggest that longitudinal studies be conducted on the influence of doing autonomous inquiry projects for science fairs on career choices in STEM. 


\section{REFERENCES}

Anderson, R. D. (2007). Inquiry as an organising theme for science curricula. In S. K. Abel, \& N. G. Lederman (Eds.), Handbook of research on science education (pp. 807-830). New York: Routledge.

Bächtold, M. (2013). What do students "construct" according to constructivism in science education? Research in Science Education, 43(6), 2477-2496. https:/ / doi.org/10.1007/s11165-013-9369-7

Bencze, J. L., \& G. M. Bowen (2009), A national science fair: Exhibiting support for the knowledge economy. International Journal of Science Education, 31(18), 2459-2483. https://doi.org/10.1080/ 09500690802398127

Bruner, J. S. (1966). Toward a theory of instruction. New York: Norton.

Capps, D. K., Crawford, B. A., \& Constas, M. A. (2012). A review of empirical literature on inquiry professional development: Alignment with best practices and a critique of the findings. Journal of Science Teacher Education, 23, 291-318. https: / / doi.org/10.1007/s10972-012-9275-2

Cohen, R., \& Swerdlik, M. (2010). Psychological testing and assessment. Boston: McGraw-Hill Higher Education.

Conklin, W., \& Manfro (2012). Higher Order Thinking Skills to develop 21st century learners. Huntington Beach, CA: Shell Education Publishing, Inc.

Crawford, B. A. (2014). From inquiry to scientific practices in the science classroom. In N.G. Lederman \& SK Abell, (eds). Handbook of research on science education (Vol. 2). London, England: Routledge.

Creswell, J. W. (2014). Research Design Qualitative, Quantitative and Mixed Methods Approaches (4th ed.). Thousand Oaks, CA Sage.

Department of Basic Education (2011). Curriculum and assessment policy statement: grade 10-12 Physical science. Pretoria: Government Printer.

diSessa, A. A., Gillespie, N. M., \& Esterly, J. B. (2004). Coherence versus fragmentation in the development of the concept of force. Cognitive Science, 28, 843-900. https://doi.org/10.1207/ s15516709cog2806_1

Driver, R., \& Bell, B. (1985). Students' thinking and the learning of science: A constructivist view. School Science Review, 67(240), 443-456.

Falk, J., \& Drayton, B. (2004). State Testing and InquiryBased Science: Are They Complementary or Competing Reforms? Journal of Educational Change 5, 345-387. https://doi.org/10.1007/s10833-0041069-7

Fosnot, C. T. (1996). Constructivism: A psychological theory of learning. In C. T. Fosnot (Ed.),
Constructivism: Theory, perspectives and practice (pp. 8-33). New York: Teachers College Press.

Gaigher, E., Lederman, N., \& Lederman, J. (2014) Knowledge about Inquiry: A study in South African high schools. International Journal of Science Education, 36(18), 3125-3147. https://doi.org/ 10.1080/09500693.2014.954156

Gomez, K. (2007). Negotiating discources: sixth-grade students' use of multiple science discources during a science fair presentation. Linguistics and education, 18, 41-64. https://doi.org/10.1016/j.linged.2007. 03.002

Grabinger, R. S., \& Dunlap, J. C. (1995). Rich environments for active learning. ALT-J, 3(2), 5-34. https://doi.org/10.3402/rlt.v5i2.10558

Hamza, K. M., \& Wickman, P.-O. (2008). Describing and analyzing learning in action: An empirical study of the importance of misconceptions in learning science. Science Education, 92, 141-164. https:/ / doi.org/10.1002/sce.20233

Hewson, P. W., \& Lemberger, J. (2000). Status as the hallmark of conceptual learning. In R. Millar, J. Leach \& J. Osborne (Eds.), Improving Science Education: the contribution of research (pp. 110-125). Milton Keynes: Open University.

Hofstein, A., \& Lunetta, V. N., (2003). The Laboratory in Science Education: Foundations for the TwentyFirst Century. Science Education, 88(1), 28-54. https:// doi.org/10.1002/sce.10106

Hume, A. (2009). Authentic Scientific Inquiry and School Science. Teaching Science, 55(2), 35-41.

Inter-Academy Panel (2011). Taking inquiry-based science education into secondary education. Report of a global conference.

Johnson, R. B., \& Onwuegbuzie, A. J. (2004). Mixed methods research: A research paradigm whose time has come. Educational Researcher, 33(7), 14-26. https:/ / doi.org/10.3102/0013189X033007014

Koomen, M. H., Rodriguez, E., Hoffman, A., Petersen, C., \& Oberhauser, K. (2018). Authentic science with citizen science and student-driven science fair projects. Science Education, 102, 593-644. https:// doi.org/10.1002/sce.21335

Kremer, K., Specht, C., Urhahne, D., \& Mayer, J. (2014). The relationship in biology between the nature of science and scientific inquiry. Journal of Biological Education, 48(1), 1-8. https://doi.org/10.1080/ 00219266.2013 .788541

Landis, J. R., \& Koch, G.G. (1977). The Measurement of Observer Agreement for Categorical Data. Biometrics, 33, 159-174. https://doi.org/10.2307/ 2529310

Lawrence, E. (1970). The origins and growth of modern education. Baltimore, M.D.: Penguin Books. 
Le Grange, L. (2008). The history of biology as a school subject and developments in the subject in contemporary South Africa. Southern African Review of Education, 14(3), 89-105.

Llewellyn, D. (2002). Inquire within. Thousand Oaks, CA: Corwin Press.

McComas, W. F. (2011). Science fair. The Science Teacher, 78(8), 34-38.

Miles, M. B., \& Huberman, A. M. (1994). Qualitative data analysis: An expanded sourcebook (2nd ed.). Sage Publications, Inc.

Mupira, P., \& Ramnarain, U. (2018). The effect of inquiry-based learning on the achievement goalorientation of grade 10 physical sciences learners at township schools in South Africa. Journal of Research in Science Teaching, 55(6), 810-825.

Naidoo, P., \& Lewin, J. (1998). Policy and planning of physical science education in South Africa: Myths and realities. Journal of Research in Science Teaching, 35(7), 729-744. https:/ / doi.org/10.1002/(SICI)1098 -2736(199809)35:7<729::AID-TEA4>3.0.CO;2-N

National Research Council. (2012). A framework for K-12 science education: Practices, crosscutting concepts, and core ideas. Washington, D. C.: National Academies Press.

NGSS Lead States. (2013). Next Generation Science Standards: For States, By States. Washington, DC: The National Academies Press.

Onwu, G. \& Stoffels, N. (2005). Instructional functions in large, under-resourced science classes: Perspectives of South African teachers. Perspectives in Education, 23(3), 79-91

Paul, J., Lederman, N. G., \& Groß, J. (2016). Learning experimentation through science fairs, International Journal of Science Education, 38(15), 2367-2387. https:/ / doi.org/10.1080/09500693.2016.1243272

Potvin, P., \& Hasni, A. (2014). Interest, motivation and attitude towards science and technology at K-12 levels: a systematic review of 12 years of educational research. Studies in Science Education, 50(1), 85-129. https://doi.org/10.1080/03057267. 2014.881626

Ramnarain, U. (2014). Teachers' perceptions of inquirybased learning in urban, suburban, township and rural high schools: The context-specificity of science curriculum implementation in South Africa. Teaching and Teacher Education, 38, 65-75.
Ramnarain, U., \& Moosa, S. (2017). The Use of Simulations in Correcting Electricity Misconceptions of Grade 10 South African Physical Sciences Learners. International Journal of Innovation in Science and Mathematics Education, 25(5), 1-20.

Rogan, J. M., \& Aldous, C. (2005). Relationship between the constructs of a theory of curriculum implementation. Journal of Research in Science Teaching, 42(3), 313-336. https://doi.org/10.1002/ tea. 20054

Saldana, J. (2009). The Coding Manual for Qualitative Researchers. Thousand Oaks, California: SAGE.

Schmidt, K. M., \& Kelter, P. (2017). Science Fairs: A qualitative study of their impact on student science inquiry learning and attitudes toward STEM. Science Educator, 25(2), 126-132.

Sund, R. B., \& Trowbridge, L. W. (1973). Teaching science by inquiry in the secondary School. Ohio: Merrill.

Syer, C. A., \& Shore, B. M. (2001). Science fairs: What are the sources of help for students and how prevalent is cheating? School Science and Mathematics, 101(4), 206-220. https:/ / doi.org/10.1111/j.1949-8594.2001. tb18023.x

Tindangen, M. (2018). Inquiry-based learning model to improve higher order thinking skills. Asian Social Science, 14(7), 39-46. https://doi.org/10.5539/ ass.v14n7p39

Travers, P., \& Rebore, R. (1987). Foundations of education: Becoming a teacher. Englewood Cliffs, NJ: PrenticeHall.

Wandersee, J. H., Mintzes, J. J., \& Novak, J. D. (1994). Research on alternative conceptions in science. In D. L. Gabel (Ed.), Handbook of research on science teaching and learning (pp. 177-210). New York: Macmillan.

Wang, S. L., \& Hodson, D. (2009). From the horse's mouth: What scientists say about scientific investigation and scientific knowledge. Science Education, 93(1), 109-130. https:/ / doi.org/10.1002/ sce.20290

White, B. Y., \& Frederiksen, J. R. (1998). Inquiry, modeling, and metacognition: Making science accessible to all learners. Cognition and Instruction, 16(1), 3-18. https://doi.org/10.1207/s1532690xci 1601_2

\section{http://www.ejmste.com}

